\title{
Non-Encapsulated Neoplasm
}

National Cancer Institute

\section{Source}

National Cancer Institute. Non-Encapsulated Neoplasm. NCI Thesaurus. Code C36036.

A neoplasm that is non-capsulated. 